\title{
Bacteriological and Physicochemical quality of Borehole water used for drinking at Olusegun Agagu University of Science and Technology, Okitipupa, Nigeria
}

\author{
Adeyemo Isaiah Adeyemi
}

Biological Sciences Department (Microbiology Unit), Olusegun Agagu University of Science and Technology, Okitipupa, Ondo State Corresponding author: adeyemiyourfriend@gmail.com;

\begin{abstract}
The concern over exposure to drinking water contaminants and the resultant adverse effects on human health has prompted several studies evaluating the quality of drinking water sources at Olusegun Agagu University of Science and Technology (OAUSTECH). Six (6) Borehole water samples were collected from three (3) functional boreholes in OAUSTECH. Two water samples from each borehole were collected using standard techniques. The physicochemical parameters analyzed include, odor, color, taste, temperature, $\mathrm{pH}$, conductivity, alkalinity, total dissolved solid, total hardness and chloride. All physicochemical parameters of the Borehole water samples were shown to be within recommended permissible limit of WHO and NAFDAC standard for potable drinking water. The bacteriological analysis of the three borehole water samples were carried out using the Most Probable Number technique (MPN). From the analysis BH1, BH2 and BH3 tested negative for total coliforms and fell within the recommended limit of WHO and NAFDAC standard for drinking water. This study has shown that water from the boreholes at Olusegun Agagu University of Science and Technology is safe for drinking. However, good and proper environmental and personal hygiene must be maintained especially by the users of these boreholes to prevent their contamination with bacteria pathogen. Boreholes should also be properly constructed with good understanding of site locations.
\end{abstract}

Keywords-Boreholes, Bacteriological analysis, physicochemical analysis, potable water.

\section{INTRODUCTION}

Water is essential for the existence of humans and all living things and hence a satisfactory (adequate, safe and accessible) supply must be available to all. Water used for domestic purposes must be clean and not contain any microorganism, parasites and other substances which can pose danger to human health [1], [2], [3]. Safe water supply and sufficient sanitation to secure health are among the essential human rights. However, many people do not have access to safe drinking water and risk to waterborne diseases is a critical public health problem in many developing countries [3]. So securing safe drinking water for all is one of the significant difficulties of the 21 st century. In a recent report, close to a billion people mostly living in the developing world do not have access to adequate and safe drinking water [3].

Control of the microbial quality of drinking water should be a priority in all countries, given the immediate and potentially devastating consequences of waterborne infectious diseases [4]. Contaminated water serves as a mechanism to transmit communicable diseases such as cholera, typhoid and guinea worm infection [5] [3]. Around $88 \%$ of diarrhea cases worldwide are linked to unsafe water, inadequate sanitation or insufficient hygiene. Most cases of diarrheal illness and death occur in developing countries with an estimated annual incidence of 4,600 million episodes and cause 2.2 million deaths every year [1]. Almost 6.1 billion people ( $89 \%$ of the world population) have used an improved drinking water source. This is $1 \%$ more than the $88 \%$ 
Millennium Development Goal target [6]. Improved sources of drinking water in developed countries has reached 99\%. In contrast, in the developing world - especially in sub-Saharan countries - the coverage is still low (63\%) with $51 \%$ and $84 \%$ coverage rates among rural and urban populations, respectively. Moreover, above $40 \%$ of all people globally who lack access to safe drinking water live in sub-Saharan Africa [6]

Water is a key component in determining the quality of our lives. Although water covers about 70 percent of the earth's total surface, only $0.3 \%$ of it can be used by humans [7]. Among the various sources of water, ground water is the largest reservoir of drinking water, it is that water reservoir found in the saturated part of the ground underneath the land surface. It normally accumulate there when the water seep into the ground and move downward due to gravity through the pore spaces found between soil particles and crack in rock. The water eventually reaches a depth where the soil and rock are saturated [8]. Ground water is an important source of water supply with a number of advantages; It is commonly free from pathogenic organism due to infiltration and requires little or no treatment; turbidity and colour are generally absent and Its chemical composition is almost stationary [9]. Despite this advantage, ground water is susceptible to pollution as a result of recent or past human activities [10]

Water from boreholes may be free from dangerous water related human diseases such as cholera, typhoid fever, dysentery, guinea worm and many others. Borehole water is ground water available in an aquifer obtained by installing a pump to draw the water to the consumers. Any contaminated surface water with pathogen that infiltrates into the soil and becomes groundwater would be filtered by the soil profile before reaching the depth of aquifer. An aquifer is saturated water bearing stratum that is capable of holding, transmitting and yielding sufficient water in underground to well. The major problems of boreholes is chemical content of the ground water, which must be analyzed to ascertain if these dissolved products are within the permissible limits for consumption purpose by the authorities such as the World Health Organization [11]. Many diseases in developing countries are caused by drinking contaminated water [12]. Quality of drinking water is fast becoming an essential aspect of water quality studies [12]. Therefore, the provision of potable water to the rural and urban population is necessary to prevent health hazards [13]..Certain minerals are also toxic such as the heavy metals. Though some of the heavy metals such zinc, manganese, nickel and copper act as micro- nutrients at lower concentrations, but become toxic at higher concentrations [14].. Health risk due to heavy metal contamination of water through soil has been reported. Therefore, auditing and monitoring of physicochemical, minerals and microbial until very recently ground water has been thought of as being a standard of water purity in itself and to a certain extent that is indeed true [15] .Groundwater pollution which is a product of human activities had profound impacts on the quality of water bodies due to the introduction of various pollutants such as organic compounds, heavy metals, agricultural waste, etc [16] Various studies confirmed the effect of heavy metals on the human health[17] Suitability of water for various uses depends on the type and concentration of dissolved minerals and ground water has more mineral composition than surface water.[18] The quality of ground water is constantly changing in response to daily, seasonal and climatic factors. Continual monitoring of water is highly crucial because changes in the quality of water have far reaching consequences in terms of its effects on man and biota[19].Contamination of ground water also depends on the geology of the area especially in limestone where extensive cavern systems are below the water table [14]. The changes in quality of groundwater response to variation in physical, chemical and biological environments through which it passes [20]. To safeguard the health of people and to reduce to the barest minimum experiences of drinking and/or using of low quality waters, it is necessary that the quality of water should be monitored with the view to finding lasting solutions to health problems associated with the use and drinking of low quality waters. Both liquid and solid waste materials dumped either on soil surface or buried are known to decompose to produce leaches that penetrate aquifers and contaminate the ground water thereby raising the potential toxicity of the water to consumers [21]

Burying and surfaces dumping of both industrial and domestic wastes are a common practice among rural and urban dwellers [22].[12] have described bore hole as a source of potable drinking and domestic use water for rural and urban population. [23] have explained that in order to understand the quality of borehole water, the physical, chemical and microbiological parameters must be analyzed. The quality of ground water however, principally depends on the elements present in it while seeping down. The World Health Organization (WHO) has set a quality guideline for drinking water and recommends that the properties of every drinking water should fall within the acceptable limit set by it [1]. The quality of water is assessed in terms of its 
physical, chemical, biological characteristics, and it's intended uses. For example, although distilled water is physically, chemically and bacteriologically pure, its taste is rather bland and it is highly corrosive [24]. It has been demonstrated repeatedly that water containing some dissolved constituents is far more palatable than pure water. Water quality varies for different purpose in every daily activity [18]. Water quality standards are standards established to determine whether water of a certain quality is suitable for its intended use. All portable water must confirm to these standards [1].

At Olusegun Agagu University of Science and Technology Okitipupa, there is not enough data on the bacteriological quality of water from boreholes sources in the university. Thus, evaluation of the bacteriological quality of these water sources will provide benchmark data about the bacteriological status and might enable insight into the development of further protective and treatment measures. Furthermore, information obtained from the present study might help in maintaining borehole hygiene and determine the sources of contamination possible to prevent outbreak of water borne diseases among the students which might prove very fatal as the population of the University is getting higher with each admission year. Therefore, the evaluation of groundwater quality is essential for the development of civilization and to establish database for future water resources strategic planning and development. Studies on groundwater have been carried out in different parts of Nigeria; however, no comprehensive study has been conducted on the groundwater quality in Okitipupa, ondo state.

\section{MATERIALS AND METHODS}

\subsection{Sample collection}

Six (6) borehole water samples from OAUSTECH study area were collected. Two (2) samples were collected from each borehole. The samples were taken from borehole of average depth 25-85 meters. All samples were collected in clean one (1) liters plastics container stored and transported in a cool box at a very low temperature into the microbiology laboratory and analyzed within 2 hours of collection.

2.2 Physicochemical Analysis

The water samples collected were analyzed for $\mathrm{pH}$, temperature, odour, colour, taste, turbidity, electrical conductivity, alkalinity, acidity, total suspended solid, total dissolved solid, total hardness and chloride

2.3 Temperature Determination
This is the degree of coolness and hotness of a system. It is an important physical parameter, determined because of its effect on living organism. Usually the temperature of polluted water is higher than the water supply due to eutrophication process and geographical location which heat up the water. This was conducted at the site of sample collection using mercury in glass thermometer

\section{$2.4 \mathrm{pH}$ Determination}

The $\mathrm{pH}$ of the water samples was determined using the Wagtech $\mathrm{pH}$ meter. $10 \mathrm{ml}$ of each of the samples was poured into a sterile beaker and the anode of the $\mathrm{pH}$ meter was dipped into it and readings were obtained when it was stable. 2.5 Determination of Colour, Odour and Taste

A $20 \mathrm{ml}$ volume of each water sample was poured into a clean beaker. The sample was then shaken vigorously to check for any frothing and allowed to settle. Colour was determined through visual examination and those odours were determined through the sensation of smell.

Taste test was determined by putting a small volume of the water sample in the tongue and then immediately raised with distilled water (taste free) after sample.

2.6 Determination of Turbidity

The digital turbidity meter (2100P) was switched on, allowed to warm up for 30 minutes. It was set at zero NTU (Neplometric turbidity unit). The cell $(60 \mathrm{ml})$ was rinsed with distilled water and filled with $60 \mathrm{ml}$ of the water sample. The side of the cell was wiped with a tissue paper to clean the digital meter and after shaking for 20 minutes. The samples were inserted in the compartment. The selection button was turned to the appropriate turbidity range $0-10$. The turbidity was then read off directly on the digital meter. The value was obtained and recorded in Nepholometric turbidity units.

2.7 Determination of Total Hardness

Total hardness was analyzed by titration of $50 \mathrm{ml}$ water sample into conical flask and $0.1 \mathrm{ml}$ of buffer solution was added or with standard EDTA. The EDTA was added in drops at $\mathrm{pH} 10$ using Erichrome black I indicator and was gently shaken until the colour change into purple, and the hardness was calculated by multiplying the average number of drops of EDTA used for the sample by the calibration factor of 20.

2.8 Mohr Method Determination of Chloride

The Mohr method uses chromate ions as an indication in the titration of chloride ion with a silver nitrate standard solution. After all the chloride has been precipitated as white sulphur chloride, the first excess of titrant results in the formation of a silver chromate precipitate which signal the end points. 
The reactions are:

$\mathrm{Ag}^{+}+\mathrm{ClAgC}$ hite precipitate

$2 \mathrm{Ag}^{+}+\mathrm{CrO}_{4}^{2-} \mathrm{ArO}_{4(\mathrm{~s})}^{-}$Yellow precipitate

$25 \mathrm{ml}$ of the Bore Hole water sample was measured and put into a conical flask and the $\mathrm{pH}$ of the sample was measured or adjusted, $1.0 \mathrm{ml}$ of the potassium chromate indicator solution was added and the solution were titrated with standard silver nitrate solution $(0.02 \mathrm{~N}$ until the pinkish yellow and point was observed. The normality of the silver nitrate end point was observed. The normality of the silver nitrate used here is $0.0141 \mathrm{~N}$ (blank) [25].

2.9 Determination of Electrical Conductivity

A $20 \mathrm{ml}$ of volume of each sample was poured into a clean beaker at room temperature. The conductivity meter (Wagtech Electrode) was switched $\mathrm{ON}$ for 10 minutes to standardize. The Wagtech Electrode was then rinsed with distilled water and was placed in the beaker containing the Bore Hole sample, and following stirring, the electrical conductivity values was determined after the pointer and the selector knob were adjusted, the reading was taken and recorded.

2.10 Determination of Total Dissolved Solid (TDS)

This is the term used for material residue that dissolves in water. Water with suspended solid may be aesthetically unsatisfactory for domestic purpose such as laundry, bathing, also water with high concentration of dissolved solid is unsuitably not potable for drinking and as well as for agriculture and industrial application or purpose. The total dissolved solids were determined by submersing the Wagtech probe into $100 \mathrm{ml}$ of each sample which the reading is taken and recorded.

\subsection{Bacteriological Analysis}

The coliform count was obtained using the 5 tube assay of the Most Probable Number (MPN) technique as described by [25]. The MPN technique for faecal coliform testing is useful in determining the faecal coliform density in most water. The technique is based on the most probable number of bacteria present in a sample [25].

\subsection{Presumptive Test}

Presumptive coliform test was performed using Macconkey broth. The first set of 5 test tubes had sterile $10 \mathrm{ml}$ double strength broth and the second 5 tubes and third sets of 5 tubes had $10 \mathrm{ml}$ of single strength broth. The test tubes are arranged in a row in three test tube racks. Each of the tubes contained Durham tubes before sterilization process was carried out using the autoclave.

Before sterilization all the test tubes containing the broth and Durham tubes were closed with non-absorbent cotton wool and then sealed with aluminum foil paper. After autoclaving for 15 minute at a temperature of $121^{\circ} \mathrm{C}$ and pressure of approximately $1.1 \mathrm{~kg} / \mathrm{cm}^{3}$. The test tube were removed from the autoclave and allowed to cool to room temperature before the borehole water samples were aseptically transferred to the sterilized tubes. The first sets of test tubes for the double strength received $10 \mathrm{ml}$ each of the borehole water sample and for the second and third sets of test tubes for the single strength received $1 \mathrm{ml}$ and $0.1 \mathrm{ml}$ of the borehole water sample respectively using sterile pipettes. The tubes were incubated at $15^{\circ} \mathrm{C}$ for $24-48 \mathrm{~h}$ for estimation of total coliform and at $44.5^{\circ} \mathrm{C}$ for faecal coliform for $24-48 \mathrm{~h}$ and examined for acid and gas production. Acid production was determined by colour change of the broth from reddish purple to yellow and gas production was checked for by entrapment of gas in the Durham tubes. A combination of positive tubes at each inoculum was compiled and the MPN index/ $100 \mathrm{ml}$ of water samples were estimated using the MPN table.

\subsection{Confirmed Test}

Confirmed test was carried out by transferring a loopful of culture from the positive tube from the presumptive test into a tube of Brilliant Green Lactose Bile (BGLB) broth (Oxide) with Durham tubes. The tubes were incubated at $37^{\circ} \mathrm{C}$ for $24-$ $48 \mathrm{~h}$ for total coliform and $44.5^{\circ} \mathrm{C}$ for faecal coliforms and were observed for gas production.

\subsection{Completed Test}

To establish the presence of coliform bacteria and to provide quality control data, the positive tube from the confirmed test was carried out by streaking a loopful of broth from a positive tube onto prepared Eosine methylene Blue (EMB) agar and prepared nutrient agar plate for pure colonies. The plates were inoculated at $37^{\circ} \mathrm{C}$ for $24-48 \mathrm{~h}$. Colonies developing on EMB agar, were further identified as coliform or faecal coliform, using cultural characteristics, morphology and biochemical tests. For faecal coliform, colonies with green metallic sheen were Gram stained and the IMVIC test was carried out on Nutrient agar stock cultures and used to identify the colony.

\subsection{Identification of Bacterial Isolates}

Stock cultures of the isolates with different cultural characteristics were made on nutrient agar slants. Gram staining was used to check for morphology and biochemical tests were performed to aid in identification. Various tests performed and used in probable identification of isolate.

\section{RESULTS AND DISCUSSION}

\subsection{Results}


The sanitary assessment of the boreholes used are as shown in Table 1 while the result obtained from the physicochemical and bacteriological analysis of borehole water in OAUSTECH are shown in Table 2.

Table 1: Sanitary Assessment of the Sampling Location

\begin{tabular}{ccccc}
\hline Sample Site & $\begin{array}{c}\text { Physical } \\
\text { Appearance }\end{array}$ & $\begin{array}{c}\text { Proximity } \\
\text { To Drainage }\end{array}$ & $\begin{array}{c}\text { Proximity } \\
\text { To Sewage Tank }\end{array}$ & $\begin{array}{c}\text { Proximity } \\
\text { To Refuse Dump Site }\end{array}$ \\
\hline BH1 & Clean & Far & Far & Close \\
BH2 & Clean & Far & Far & Far \\
BH3 & Clean & Close & Close & Far \\
BH4 & Clean & Close & Far & Far \\
\hline
\end{tabular}

\section{Keys:-}

BH - Borehole

BH1 - Borehole at Car park

BH 2 - Back of ICT block

BH 3 - Microbiology laboratory close $\leq 15$ meters from pollution source

far $\geq 20$ meters from pollution source

Table 2: Bacteriological and Physicochemical Parameters of water from sampled Boreholes.

\begin{tabular}{|l|l|l|l|l|l|l|l|l|}
\hline & $\mathrm{pH}$ & $\begin{array}{l}\text { Electrical } \\
\text { Conductivity } \\
(\mu \mathrm{S} / \mathrm{cm})\end{array}$ & $\begin{array}{l}\text { Tempera } \\
\text { ture }\left({ }^{0} \mathrm{c}\right)\end{array}$ & $\begin{array}{l}\text { Total } \\
\text { dissolved } \\
\text { solid(ppm) }\end{array}$ & $\begin{array}{l}\text { Alkalinity } \\
\mathrm{Mg} / \mathrm{L}\end{array}$ & $\begin{array}{l}\text { Total } \\
\text { hardness } \\
(\mathrm{ppm})\end{array}$ & $\begin{array}{l}\text { Chloride } \\
\mathrm{Mg} / \mathrm{L}\end{array}$ & $\begin{array}{l}\text { Most } \\
\text { probable } \\
\text { number } \\
(\mathrm{MPN} / 100 \mathrm{ml})\end{array}$ \\
\hline Borehole 1 & 6.50 & $50.7 \mu \mathrm{s} / \mathrm{cm}$ & $35.8^{0} \mathrm{c}$ & $3.52 \mathrm{mg} / \mathrm{L}$ & $0.20 \mathrm{mg} / \mathrm{L}$ & $10.77 \mathrm{mg} / \mathrm{L}$ & 69.00 & 0 \\
\hline Borehole 2 & 7.20 & $179.6 \mu \mathrm{s} / \mathrm{cm}$ & $32.1^{0} \mathrm{c}$ & $0.10 \mathrm{mg} / \mathrm{L}$ & $53.40 \mathrm{mg} / \mathrm{L}$ & $151.06 \mathrm{mg} / \mathrm{L}$ & 1.37 & 0 \\
\hline Borehole 3 & 6.80 & $11.2 \mu \mathrm{s} / \mathrm{cm}$ & $30.7^{0} \mathrm{c}$ & $22.77 \mathrm{mg} / \mathrm{L}$ & $28.50 \mathrm{mg} / \mathrm{L}$ & $151.00 \mathrm{mg} / \mathrm{L}$ & 5.10 & 0 \\
\hline $\begin{array}{l}\text { WHO } \\
\text { guideline }\end{array}$ & $\begin{array}{l}6.8- \\
8.5\end{array}$ & $\begin{array}{l}\leq \\
400 \mu \mathrm{S} / \mathrm{cm}\end{array}$ & $25-39$ & $<1000$ & $20-200$ & $<500$ & $\leq 250$ & 0 \\
\hline
\end{tabular}

\subsection{Discussion}

Table 1 revealed the sanitary assessment of the sampling locations, all the locations of the borehole water samples were clean. However, serious efforts should be made to maintain and sustain this level of hygiene as dirty environment can pollute the underground water and also lead to high prevalence of diseases like cholera, typhoid fever etc. which lead to high mortality rate. The table also showed that the appearance of all the borehole water sample is clear, it was also odourless, tasteless and colourless and they fell within the World Health Organization and National Agency for Food and Drug Administration and Control (NAFDAC) standard for drinking water. These could be due to the absence of particles and non- accumulation of solid and slits. Colour in natural water usually result from leaching of organic materials and is primarily the result of dissolved and colloidal humic substance, primarily humic acid and fluvic acid. However the overall colour do not pose any health threat to those that use the water.

Table 2 showed the various biological and physico-chemical parameters measured to ascertain the potability of water from sampled boreholes. The $\mathrm{pH}$ value ranged from 6.5 to 7.9, which falls within the recommended standard for drinking water standard. Water is said to be safe of the concentration 
of the substance do not exceed the level set by the regulatory bodies.this is consistent with results obtained by [27]. The World Health Organization [28] recommends a $\mathrm{pH}$ value of 6.5 or higher for drinking water to prevent corrosion. Although, a $\mathrm{pH}$ above 8.0 would be disadvantageous in the treatment and disinfection of drinking water with chlorine [29]. However, $\mathrm{pH}$ values between 6.5 and 8.5 usually indicate good water quality and this range is typical of most drainage basins of the world [30]

The Temperature of any water body affects the rate of proliferation of micro- organisms[16]. The Temperature values ranged from 30.7 to $35.8^{0} \mathrm{c}$, falling within the recommended permissible level of WHO and NAFDAC standard for drinking water standard of $25-39^{\circ} \mathrm{C}$ as the temperature varies across different regions of the world. high temperature negatively impact water quality by enhancing the growth of micro-organisms which may increase taste, odour, colour and corrosion problems [28]. Therefore, it is important that groundwater temperature is not too high in order not to have microbial proliferation. Temperature affects biological, chemical and physical activities in the water [30]. Besides, increase in temperature of water decreases solubility of gases such as $\mathrm{O} 2, \mathrm{CO} 2, \mathrm{~N} 2$ and $\mathrm{CH} 4$ [30]

The conductivity value ranged from 11.2 to $179.6 \mu \mathrm{s} / \mathrm{cm}$ falling within the recommended standard, of WHO and NAFDAC for drinking water standards, indicatives of the absence of dissolved minerals and presence of some ions in low levels, thus conductivity was well below the standards of the regulatory bodies and therefore fell within the permissible limit for potable drinking water. Conductivity of the groundwater for the entire study area stands at an average of $80.5 \mu \mathrm{S} \mathrm{cm}-1$ and it is in accordance with the findings of [31] which submit that values within the permissible WHO standards give a picture of very little solute dissolution generally in the groundwater, rapid ion-exchange between the soil and water, or basically a poor and rather insoluble geologic rock and mineral types.

The values for Alkalinity ranged from 0.20 to $53.4 \mathrm{mg} / \mathrm{L}$ which fell within the WHO and NAFDAC recommended standard for drinking water. Total dissolved solid values ranged from 0.27 to $22.77 \mathrm{mg} / \mathrm{L}$ which fell within the permissible level recommended standard of WHO and NAFDAC. The total suspended solid values ranged from 0.02 to $3.52 \mathrm{mg} / \mathrm{L}$, fell within the recommended standard by the regulatory bodies. The Total Hardness of water is not a specific constituents but is a variable and complex mixture of cations and anions. Principally the water hardness are changed by ions such as calcium and magnesium. The total hardness from the bore hole water samples analyzed ranged from 3.30 to $151.06 \mathrm{mg} / \mathrm{L}$ fell within the permissible level of WHO and NAFDAC standard for potable drinking water from the result the total hardness analyzed is either soft or moderately hard .Soft water are associated with rickets in children and have been found to be statistically related to high mortality from cardio vascular diseases. Very hard water is not good for drinking and is associated with rheumatic pains and goiter [32]

The bacteriological analysis using Most Probable Number technique (MPN), showed that only all the Borehole water samples were free from the presence of coliforms which probably might have resulted from the clean environment. Potable water should be totally devoid of coliform. Borehole water samples from $\mathrm{BH} 1 \mathrm{a}, \mathrm{BH} 1 \mathrm{~b}, \mathrm{BH} 2 \mathrm{a}, \mathrm{BH} 2 \mathrm{~b}, \mathrm{BH} 3 \mathrm{a}$ and $\mathrm{BH} 3 \mathrm{~b}$ all fell within the recommended standard of $\mathrm{WHO}$ and NAFDAC standard for drinking water standard have no presence of coliform. This results corroborates the finding of [17] that the MPN coliform index per $100 \mathrm{ml}$ of water sample collected from selected Bore Holes in Ilorin metropolis ranged from 0 to $16 \mathrm{MPN} / 100 \mathrm{ml}$. The presence of total coliforms in groundwater indicates that the groundwater sources may be vulnerable to contamination by more harmful microorganisms hence the water samples are all fit for human consumptions as they have no such coliforms. This result coincides with the results of [33]; [34] [34] 18] who all posited that except groundwater is contaminated, it should be naturally free from faecal coliform and fall to the $0 \mathrm{MPN} / 100 \mathrm{ml}$ standard recommendation by the WHO.

\section{CONCLUSION}

Temperature, $\mathrm{pH}$, conductivity, total dissolved solids, alkalinity and electrical conductivity, of groundwater in OAUSTECH were studied. Temperature values are consistent with tropical belt, it can be considered as being ambient relative to the geographical region and good enough in terms of supporting microbial growth. Average $\mathrm{pH}$ is slightly acidic and indicates susceptibility of metals and pipes to easy corrosion problems. The values of Electrical conductivity and total dissolved solids give a measure of the ionic load and contaminants in the water. Hence, from the EC and TDS values, the groundwater of this study area can be said to have low salt concentration and good for drinking 
and crop production. Furthermore, the $\mathrm{pH}$ and $\mathrm{EC}$ values infer that the water is clearly not saline and suggest its possible likelihood for irrigation agriculture. Although, other factor like Sodium Absorption Ratio (SAR) and Residual Sodium Carbonate (RSC) of the groundwater will have to be studied. Meanwhile, findings suggest that the groundwater in this aquifer is fresh. All parameters clearly fell below WHO international best standards for water quality.

Therefore, from results of this study, the groundwater in the study area can be regarded as being of good quality for drinking and agriculture purposes with reference to the parameters under consideration, although with little $\mathrm{pH}$ treatment because of its slight acidity. However, further studies with reference to the chemical and microbial analyses will have to be done to have a broader picture of this water quality.

\section{REFERENCES}

[1] WHO (2011). Guidelines for Drinking-Water Quality, Vol. 38, 4th edn. World Health Organization, WHO, Geneva, Switzerland, pp. 104-108

[2] Alvarez-Bastida C., Martínez-Miranda V., Solache-Ríos M., Hernández I. L., Teutli-Sequeira A. \& Mejía G. V. (2018): Drinking water characterization and removal of manganese. from water. J. Environ. Chem. Eng. 6, 2119-2125

[3] Khalid S., Murtaza B., Shaheen I., Ahmad I., Ullah M. I., Abbas T., Rehman F., Ashraf M. R., Khalid S. \& Abbas S. 2018 Assessment and public perception of drinking water quality and safety in district Vehari, Punjab, Pakistan. J. Clean. Prod. $181,224-234$

[4] WHO/UNICEF (2017): Progress on Drinking Water, Sanitation and Hygiene: 2017 Update and SDG Baselines. World Health Organization, Geneva, Switzerland and UNICEF, New York, USA.

[5] WHO (2013): Water Quality and Health Strategy 2013-2020. World Health Organization, Geneva, Switzerland

[6] UNICEF (2012): Progress on Drinking Water and Sanitation: 2012 Update. UNICEF, New York, USA

[7] Eniola, K. I.T., Obafemi, D.Y., Awe, S.F., Yusuf, I.I., and Falaiye, O.A. (2007). Effects of container and storage conditions of bacteriological quality of borehole water. Nigeria Journal of Microbiology 21(3):1578-1585.

[8] Samie A., Makonto T., Odiyo J., Ouaboi-Egbenni P., Mojapelo P. \& Bessong P. (2011): Microbial quality, diversity and antibiotic susceptibility profiles of bacterial isolates from borehole water used by schools in Greater Giyani Municipality, Mopani District, South Africa. Afr. J. Microbiol. Res. 5, 198 210

[9] Al-Kasimi, S.M. (2002). Existence of Ground vapour-flux up flow: profit and utilization of planting the Desert using
Reflective carpet Dahran. Journal of Environmental Science 3: 105-119.

[10] Adogo, I.Y., Ajiji,M.A., Anyanwu, N.O.J. and Ajide, B.(2016): Bacteriological and Physicochemical Analysis of Borehole water in Auta Balefi Community ,Nassarawa State ,Nigeria. British Microbiology Research Journal 11(4):1-7.

[11] World Health Organization-WHO (2006). Guideline for drinking water quality. Volume 1 Geneva Addendum to the $3^{\text {rd }}$ volume 1 Recommendations WHO. 23-48.

[12] Asuguo, J.E. and Etim, E.E. (2012).Physicochemical and Bacteriological studies of selected Borehole water in Uyo, Akwa Ibom State, Nigeria. International Journal of Modern Chemistry 2 (1):7-14.

[13] Chilton, J. (1996).Aquifers as Environments for microbial activity. In: proceedings of the International Symposium on Environmental Aspects of Microbiology, Sigtuna, Sweden 2: 293-304.

[14] Ibekwe, A.M., Murinda, S.E. and Graves, A.K. (2011). Microbiological Evaluation of Water Quality from Urban Watersheds for domestic water supply improvement. International Journal of Environmental. Res. Public Health 8(12): 466076.

[15] Asante, F. (2013). Bioaccumulation of heavy metal on water, sediments and tissues of some selected fishes from the Red Volta of Ghana. British journal of Applied Science and Technology 6(2): 594-803.

[16] Adekunle, M.T., Gbadebo, A.M. and Banyoko, O.B. (2009). Assessment of Ground water quality in a typical rural settlement in south west Nigeria. International Journal of Environmental Research and Public Health 6:307-318

[17] Agbabiaka, T.O. and Sule, I.O. (2011). Bacteriological assessment of selected borehole water sample in Ilorin metropolis. International Journal of Applied Biological Research 2(2):31-37.

[18] Boulding and Rusell, J. (1995). Ground water contamination; assessment, prevention and remediation; Practical Handbook of Soil, Vadose Zone, Boca Raton, Fl: Lewis Publishers 25-13.

[19] Balakrishan, P., Saleem, A. and Malikarjun, N.D. (2011). Ground Water Quality Mapping using Geographic Information System (GIS). A case study of Gulbarga City, Karnataka, India. African Journal of Environmental Science Technology 5(12):1069-1084.

[20] Anim, A.K., Duodu, G.O. and Ahialey, E.K. (2011). Assessment of surface water quality. The perspective of the weija dam, Ghana. International Journal of Chemistry 3(2):3239.

[21] Edema, M.O., Omemu, A.M. and Fapeju, O.M. (2001). Microbiology and Physicochemical Analysis of Different Sources of Drinking water in Abeokuta, Nigeria. Nigeria Journal of Microbiology 15(1):57-67.

[22] Adeyemi I.A, Alhassan A, Temitayo A.A, Muhammed O.A and James O.A (2014). A study of Aspergillus niger hydrolysed cassava peel as a carbohydrate source on the 
histology of broiler chickens.Springerplus 3: 31. doi: 10.1186/2193-1801-3-31

[23] Chidinma, L.U., Emmanuel, C.N. and Nennaya, R.T. (2016). Physicochemical and Bacteriological Assessment of some Borehole waters in the Federal Capital Territory, Nigeria. International Research Journal of Public and Environmental Health 3(6):140-145.

[24] De-simone, L.A.M., Hamilton, P.A. and Gillion, R.J. (2009). Quality of water from domestic wells in principal aquifers of the United States. Overview of major findings. United States geological survey circular 1: 1332-48.

[25] APHA., 2005. Standard Methods for the Examination of Water and Wastewater. 21st Edn., American Public Health Association/American Water Works Association, Washington, DC., USA.

[26] Ahaneku, I.E. and P.A. Adeoye, 2014. Impact of pit latrines on groundwater quality of Fokoslum, Ibadan, Southwestern Nigeria. Br. J. Applied Sci. Technol., 4: 440-449.

[27] WHO, 2010. Guideline for Drinking Water Quality. 3rd Edn., World Health Organization, Geneva, Switzerland.

[28] UNICEF, 2008. UNICEF Handbook on Water Quality. United Nations Children's Fund (UNICEF), New York, USA., Pages: 179.

[29] UNEP/GEMS, 2007. Water quality outlook. United Nations Environmental Programme (UNEP)/Global Environmental Monitoring System (GEMS), Burlington, Ontario, Canada.

[30] Yilmaz, E. and C. Koc, 2014. Physically and chemically evaluation for the water quality criteria in a farm on Akcay. $J$. Water Resour. Prot., 6: 63-67.

[31] H.H. Oyem, I.M. Oyem and D. Ezeweali, (2014). Temperature, $\mathrm{pH}$, Electrical Conductivity, Total Dissolved Solids and Chemical Oxygen Demand of Groundwater in BojiBojiAgbor/Owa Area and Immediate Suburbs. Research Journal of Environmental Sciences, 8: 444450.DOI: $10.3923 /$ rjes.2014.444.450,

URL: https://scialert.net/abstract/?doi=rjes.2014.444.450

[32] Bahar, M. and M.S. Reza, 2010. Hydrochemical characteristics and quality assessment of shallow groundwater in a coastal area of Southwest Bangladesh. Environ. Earth Sci., 61: 10651073.

[33] Eltahir Y. M. \& Abdelrahman A. A. 2013 Bacterial contamination of drinking water in the internally displaced people camps in South Darfur, Sudan. Comput. Water Energy Environ. Eng. 2,10.

[34] Bello O., Osho A. \& Bello T. 2013 Microbial quality and antibiotic susceptibility profiles of bacterial isolates from borehole water used by some schools in Ijebu-Ode, Southwestern Nigeria. Sch. Acad. J. Biosci. 1, 4-13. 